talnej (syryjskiej i koptyjskiej). Było to z pewnością planowanie na wyrost. Nie ma bowiem do dzisiaj obsady dla Katedry Filologii Patrystycznej, a dla Katedry Orientalnej jest ona tylko p.o. Ks. Stanula miał jednak nadzieję, że dla literatury syryjskiej znajdzie specjalistę (myślał o swoim współbracie w Zakonie!). Wydział Teologiczny jednak nadal potrzebowal patrologii, ale specjalność patrystyczna została tak rozbudowana, że nie mogła w całości wrócić na teologię. Wówczas ks. Stanula przez cały czas wykładał kurs patrologii na studiach dziennych i zaocznych na Wydziale Teologicznym. Co więcej, powstawało także wiele prac dyplomowych na innych seminariach Wydziału Teologicznego (gdy przeglądniemy ich tematykę, z łatwością znajdziemy oddziaływanie serii PSP). Na Wydziale Kościelnych Nauk Historycznych i Spolecznych pod patronatem ks. Stanuli powstały trzy doktoraty, a w trzech innych doktoratach uczestniczył jako recenzent. Pominę liczne prace magisterskie (znajdują się w odpowiednich wykazach). We wspomnieniu świadomie pominąłem jego dokonania naukowe, do których m.in. należą thumaczenie pism św. Hilarego, które miejmy nadzieje Uniwersytet Kardynała Stefana Wyszyńskiego wyda, oraz prace badawcze z teologii biblijnej IV wieku. Myślę, że zasługują na osobne opracowanie: może magisterium z dziedziny historii patrologii w Polsce?

Ks. Wincenty Myszor

\title{
KS. EMIL STANULA JAKO DUSZPASTERZ AKADEMICKI
}

W 1960 roku ks. prof. E. Stanula, po ukończeniu Seminarium Duchownego rozpoczął studia filologii klasycznej na Uniwersytecie Jagiellońskim i tam również zaczął swoją działalność duszpasterską w środowisku akademickim. Ks. A. Rębacz wspomina: „Z osobistych z nim rozmów dowiadywałem się o bardzo ciekawych dyskusjach tak z kolegami z roku jak i z asystentami na tematy religijne. Były to lata 1960 - 1965, a więc czasy komunizmu, a jednak O. Emil chodził na wszystkie zajęcia w habicie. Uważał, że ten znak był potrzebny w środowisku uniwersyteckim, właśnie ze względów duszpasterskich." To za jego staraniem w roku 1962 zostało powołane Duszpasterstwo Akademickie przy miejscowym kościele oo. Redemptorystów w Krakowie. „Była to forma dotąd w tym środowisk nie praktykowana”. O. Emil przekonał wszystkich swoich współbraci o takiej potrzebie. Dzięki temu grupa 30 - 50 osób mogła się co niedziela spotkać na osobnej Mszy świętej w kaplicy klasztornej, a potem „dyskutować” w świetlicy. Choć studia filologiczne wymagają dużej pracy, to jednak mimo pomocy ze strony współbraci, niedzielne kazania w latach 1962 - 1965 do młodzieży akademickiej wygłaszał najczęściej On sam.

Ks. Stanula uważał za konieczne urządzanie zamkniętych rekolekcji dla studentów. Początkowo miały one miejsce w salkach katechetycznych przy klasztorze. Ponieważ salki te nie miały zaplecza kuchennego, posiłki przynoszono z kuchni klasztornej, co było bardzo niewygodne i kłopotliwe. Potem O. Emil znalazł inne rozwiązanie: zamawiał obiady dla całej grupy w pobliskim barze. Jak to załatwiał, 
pozostanie Jego tajemnicą. Następnym etapem było korzystanie z domu rekolekcyjnego SS. Karmelitanek w Czernej.

Po przeniesieniu się do Warszawy, przy parafii swego zgromadzenia pod wezwaniem św. Klemensa tworzy, wzorem Krakowa, ośrodek duszpasterstwa akademickiego. Również tutaj łączy posługę kapłańską ze studiami na Akademii Teologii Katolickiej. Był duszpasterzem akademickim w latach 1965 - 1974. Pełnił również funkcję duszpasterza akademickiego dekanatu Warszawa-Wola. Pod opieką ks. Emila Stanuli znaleźli się studenci wydziałów farmacji i wydziału ogólnolekarskiego mieszkający w akademiku na Karolkowej. Dla nich i dla studentów innych uczelni, którzy szybko się dowiedzieli o istnieniu ośrodka i o jego duszpasterzu, odprawiał Mszę świętą. Wyprzedzając odpowiednie rozporządzenia, odprawiał w języku polskim. Prowadził również dla studentów rekolekcje, dni skupienia, a także konwersatoria, przybliżając im także pisma Ojców Kościoła. Jako pierwszy zaczął chodzić do akademika z wizytą duszpasterską, a trwało to dość długo, bo około pół roku. Prowadził wtedy indywidualne rozmowy ze studentami. Również co roku, przy zachowaniu pewnej ostrożności, w pierwszą niedzielę maja studenci ze swoim Opiekunem udawali się z pielgrzymką na Jasną Górę. Organizował obozy i zjazdy młodzieży akademickiej, a wszystko to było bardzo starannie przygotowane, mimo iż czyniono to nieoficjalnie. Przez krótki okres był też ks. Stanula katechetą szkół średnich.

Znajomości z lat działalności w ośrodku duszpasterstwa akademickiego podtrzymywał z wieloma osobami aż do końca, dając im śluby, udzielając sakramentu chrztu św. ich dzieciom, biorąc udział w wigiliach w ich domach. W późniejszym okresie organizował również spotkania Rodzin i obozy Rodzin.

W czasie, kiedy pisał doktorat (na przełomie lat sześćdziesiątych i siedemdziesiątych) ks. Emil wycofał się z funkcji duszpasterza akademickiego. Nie znaczy to jednak, że przestał udzielać się ludziom. W dalszym ciągu służył pomocą w duszpasterstwie w formie spowiedzi oraz głoszenia kazań i homilii. Kilkakrotnie prowadził rekolekcje wielkopostne i adwentowe dla świeckich, a także rekolekcje dla zakonnic i kleryków seminariów duchownych. Na zaproszenie ks. Lorka kilkakrotnie prowadził rekolekcje u OO. Bonifratrów w Warszawie. Kilka razy jeździł na rekolekcje wielkopostne do Głogowa. Ks. Stanula był też bardzo wyczulony na potrzeby ludzi, starając się zawsze, nawet z narażeniem, przychodzić z pomocą tym, którzy potrzebują. Stąd to opieka, w okresie PRL nieoficjalna (ukryta), nad rodzinami wojskowych, a miał ich wiele; kiedy zaszła potrzeba, jechał w umówione miejsce, dawał śluby, chrzcił dzieci, udzielał Pierwszej Komunii.

W latach osiemdziesiątych O. Emil rozszerzył swoją działalność duszpasterską przez popularyzację antyku chrześcijańskiego, wygłaszając różnorodne odczyty i prelekcje na tematy patrystyczne. W Polskim Radio przybliżał słuchaczom postać św. Augustyna, w Radio zaś „Maryja” występował z pogadankami na temat Ojców Kościoła. Wygłosił również cykl odczytów dla Sióstr Loretanek w Warszawie i w Loretto pod Wyszkowem. W tym Zgromadzeniu przez kilka lat prowadził też spotkania Sylwestrowe, tzn. Mszę świętą i okolicznościową homilię. Ostatni cykl wykładów z patrologii wygłosił w 1998 w Zgromadzeniu „Małe Siostry Jezusa” 
w Zielonce koło Warszawy. Polegały one na czytaniu tekstów wybranych Ojców Kościoła i ich komentowaniu. Ks. Stanula był również zapraszany z katechezą do OO. Bazylianów na Miodowej w Warszawie oraz do Sióstr Sług Maryi (Bazylianek), a także do parafii grecko - katolickiej w Koszalinie.

Co roku w lipcu, w czasie tygodniowego odpustu w Tuchowie, był bardzo gorąco oczekiwany w swej rodzinnej miejscowości - Szerzynach, i na ile pozwalały mu obowiązki a potem zdrowie, to przyjeżdżał. Będąc młodym pracownikiem naukowym na Akademii Teologii Katolickiej opiekował się najpierw teatrem (1970-1972), a potem chórem (1972-1977), dbając nie tylko o poziom artystyczny, ale także o stronę duchową tych zespołów. Ponadto dwukrotnie uczestniczył w procesach beatyfikacyjnych, abpa Szczęsnego Felińskiego i kardynała Stefana Wyszyńskiego. Brał też cztery razy udział w kapitułach zakonnych Polskiej Prowincji Ojców Redemptorystów.

Jak wspomina o. Rębacz: „Zarówno w czasach krakowskich jak i w Warszawie, jego konfesjonał był zawsze „oblegany” przez penitentów. Miał niezwykły dar rozpoznawania ludzkich problemów i w najtrudniejszych sytuacjach potrafił budzić nadzieję". A duszpasterskie wyczulenie na potrzeby napotkanych ludzi pozostało w nim do końca. Nawet w dyscyplinę naukową, którą się zajmował, wprowadzał duszpasterskie znamię.

Iwonna Salamonowicz-Górska 